\title{
Effect of blanching and drying treatment on the proximate composition of Moringa oleifera leaves
}

\author{
R.B. KSHIRSAGAR, A.R. SAWATE, S.K. SADAWATE, B.M. PATIL AND M.A. ZAKER
}

Received : 24.10.2016; Revised : 03.02.2017; Accepted : 17.02.2017

See end of the Paper for authors' affiliation

Correspondence to :

\section{R.B. KSHIRSAGAR}

Department of Food Engineering, College of Food

Technology, Vasantrao Naik

Marathwada Krishi

Vidyapeeth, PARBHANI (M.S.)

INDIA
- ABSTRACT : This research was carried out to investigate the influence of different blanching and drying methods on the proximate composition of Moringa oleifera L. Fresh sample of Moringa leaves were collected, sorted, blanched (boil blanched, steam and boil blanched with $\mathrm{Na}_{2} \mathrm{CO}_{3}$ ) and dried using different methods. The blanched and dried plant samples were analysed separately for proximate composition using appropriate methods. The protein content in the blanched Moringa oleifera leaves powder decreased from the unblanched Moringa oleifera leaves powder sample. The highest fat content in the boil blanched + sodium bicarbonate blanched sample was recorded $(2.1 \%)$ and lowest fat contained in the sample of boil blanched $(1.5 \%)$ was recorded. Steam blanching method observed superior among all blanching treatments. It retained maximum amount of crude protein, carbohydrate and crude fibre while crude fat was much more when steam blanching used. Cabinet tray dried leaves powder retained higher protein and fat content as compared to other dried powders.

- KEY WORDS : Moringa oleifera leaves, Blanching, Drying, Proximate composition

- HOW TO CITE THIS PAPER : Kshirsagar, R.B., Sawate, A.R., Sadawate, S.K., Patil, B.M. and Zaker, M.A. (2017). Effect of blanching and drying treatment on the proximate composition of Moringa oleifera leaves. Internat. J. Agric. Engg., 10(1) : 10-15, DOI: 10.15740/HAS/IJAE/10.1/1015. 